ISSN 2614-6649 (ONLINE)

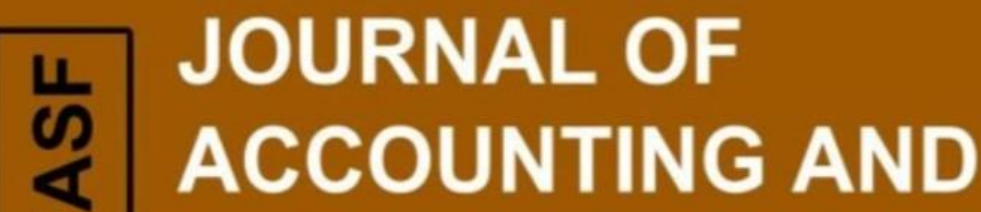 STRATEGIC FINANCE
}

The Effect of Organizational, Individual, and Demographic Factors on the Whistle-blowing Intention

Yustrida Bernawati, Giovani Beatrice Napitupulu

Determinant Analysis of Residual Net Income in The Sharia Coopera-

tive: Company Size as Mediator

Bulan Karima Nurani, Hasan Mukhibad

Effect of Rupiah Exchange Rate, GDP Growth, and Dow Jones Index on Composite Stock Price Index in Indonesia Stock Exchainge

Safitri Oktavia, Wiwik Handayani

Effect of Use of Management Accounting Systems on Competitive Advantages: Business Unit Performance as a Mediator (Study of MSMES

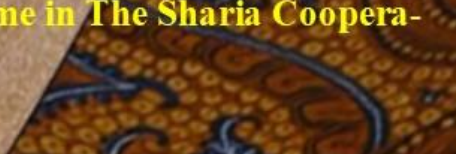
in Palembang City)

Delfi Panjaitan, Desy Lesmana, Mutiara Maimunah

Earning Management Analysis before and after Implementation of International FinancialReporting Standards (IFRS): Empirical Study of Automotive and Components Companies Registered on the IDX Anis Purwanti, I Wayan Wisnu Utama ocoosogo

Factors Influencing the Stock Price of Banking Companies in the Indonesia Stock Exchange

Muria Kartika Perdana, Constance Henryette Adriana
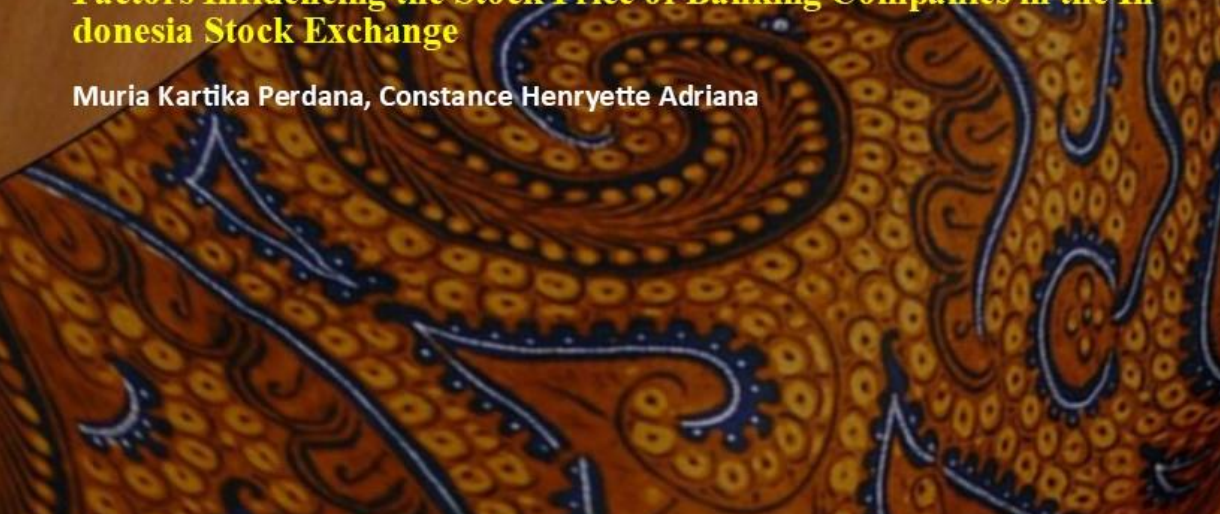


\title{
EFFECT OF USE OF MANAGEMENT ACCOUNTING SYSTEMS ON COMPETITIVE ADVANTAGES: BUSINESS UNIT PERFORMANCE AS A MEDIATOR (STUDY OF MSMES IN PALEMBANG CITY)
}

\author{
Delfi Panjaitan$^{1}$, Desy Lesmana², Mutiara Maimunah ${ }^{3}$ \\ ${ }^{1,2,3}$ Accounting Department, Faculty of Economics, Catholic University of Musi Charitas, Kampus \\ Bangau, Jalan Bangau No.60, Palembang 30113, Indonesia.
}

Received: August 12, 2018. Revised: October 20, 2018. Accepted: October 24, 2018

\begin{abstract}
Micro, Small, and Medium Enterprises (MSMEs) are business units managed by community groups and families. SMEs has a strategic role in Indonesia economic development, because in addition to contributing to national economic growth it can also absorb large numbers of workers. However, micro, small and medium businesses have a low competitive advantage in the current era of globalization and technology. For this reason, MSMEs need resources that can be managed to win business competition in Indonesia. One of the most important resources managed in winning business competition is information resources. This study aims to prove the influence of the use of management accounting systems on competitive advantage, with business performance as a mediator. The data of this study were collected through a survey by distributing questionnaires. The sample in this study was MSMEs scale company in the city of Palembang using the purposive sampling method. Data analysis technique uses path analysis test. Based on data and research results it can be concluded that Business Unit Performance mediates the relationship between Management Accounting Systems and Competitive Advantages.
\end{abstract}

Keywords: Management Accounting System, Competitive Advantage, and Business Unit Performance

How to cite (APA $6^{\text {th }}$ style)

Panjaitan, D., Lesmana, D., \& Mimunah, M. (2018). Effect of Use of Management Accounting Systems on Competitive Advantages: Business Unit Performance as a Mediator (Study of MSMEs in Palembang City). Journal of Accounting and Strategic Finance, 1 (01), 33-44

\section{INTRODUCTION}

Micro, Small and Medium Enterprises (MSMEs) are business sectors that have an important role in Indonesia economy. MSMEs are the economic support of a country in facing various crises. Chairman of the CIDES Board of Directors (Center for Information and Development Studies) Rohmad Hadiwijoyo said there are three factors that make micro, small and medium enterprises (MSMEs) able to survive in crisis economic conditions (Meryana, 2012). First, MSMEs generally produce consumer goods and services that are close to people's needs. Second, use of local resources, such as human resources, capital, raw materials, and other resources without carrying out import activities. Third, MSMEs are not supported by bank loan funds, rather utilizing their own capital.

Currently MSMEs or Micro, Small and Medium Enterprises are in great demand by many people in Indonesia. No wonder the MSMEs are the largest business group in Indonesia and contribute to Indonesia's economic growth by $60 \%$ (Choiri, 2018; Putra, 2018). In terms of employment, it reached $97 \%$ and contributions to the national economy reached $99.9 \%$. The role of MSMEs on the Gross Domestic Product (GDP) reaches 60.34\% (Putra, 2018). In the era of glob- 
alization, traditional MSMEs management is not an adequate strategy. Although globalization opens up many business opportunities, it also challenges foreign competitors that threaten MSME growth (Suryaningrum, 2012). The big opportunity of MSMEs business is shown by the projections of Frost \& Sullivan, Indonesia's e-commerce market is estimated to grow $31 \%$ per year rapidly, exceeding US \$ 3.8 billion in 2019. Its growth rate is far above the Asia Pacific e-commerce market which is estimated to average average of only $26 \%$ per year, or reaching US $\$ 79$ billion in 2020. In the next five years Indonesia's e-commerce industry will grow with an economic value of around US \$ 15 billion, and in 2025 it can penetrate US \$ 80 billion. Based on research conducted by Deloitte in 2015 on around 437 SMEs in Indonesia, SME entrepreneurs who have been connected to the internet were able to feel more benefits. They can get access to new customers not only in the territory of Indonesia but also internationally (Chandra, 2018).

However, despite having a strategic role, developing MSMEs is not an easy matter. MSMEs have low competitive advantages, including in terms of inefficient costs, lack of product uniqueness, and lack of focus on certain segments (Danial, 2017). According to Porter (1985; xv), competitive advantage is at the heart of a company's performance in a competitive market ... Competitive advantage is about how a company actually puts generic strategies into practice. Furthermore, according to Porter $(1985$, p. 3$)$, competitive advantage grows fundamentally from the value that allows companies to create that value for buyers beyond the costs incurred by the company to create it.

Previous research proves that competitive advantage is influenced by several factors, including factors in the use of management accounting information systems, business performance, product quality, product innovation, and prices (Motaher, 2009; Jaf, Sabr, and Nadir, 2015; Apriliani, 2015; Kasravi, Ghasemi, and Zadeh, 2017). Therefore, the purpose of this study is to prove the effect of the use of information of management accounting systems on competitive advantage with business performance as a mediator.

Fred David $(2011,9)$ defines competitive advantage as "whatever companies do better than rival companies". When a company can do something that a rival company cannot do or has something that a rival company wants, then it can represent a competitive advantage. An organization should be careful in measuring profits and costs to improve market strategy orientation that might hinder performance. Strategy is the most planned plan regarding the description of products, activities, functions and markets currently carried out by the company to achieve the company's main objectives. The strategy is based on the company's excellence in facing the environment. Competing strategies are different businesses from competitors in the same industry (Porter, 1985). Every company has the freedom to determine which strategies will be used in competing. Thus, competitive advantage is the ability of companies to gain economic benefits above the profits that can be achieved by competitors in the market in the same industry. Companies that have competitive advantages always have the ability to understand changes in market structure and are able to choose effective marketing strategies.

One of the factors that influence business competitive advantage is the use of information of management accounting system. Motaher (2009) examines the use of managers in benchmarking and monitoring available information systems. The involvement of benchmarking in comparing a company with competitors is a relevant factor, including costs and structure costs, productivity, quality, price, customer service, and profitability. Motaher's research results proved that the use of information of management accounting systems has a positive effect on competitive advantage. Corporate organizations in general are able to gain competitive advantage if the position held by the company is able to provide prominent strength above the competitor's strength, and the ability to build the company's product image against the customer (product positioning). Competitive advantage can be achieved if the company has a competitive strategy. The competitive strategy is a combination of the ultimate goals the company wants to achieve with the tools (policies) where the company tries to get there. Porter (1985) classifies excellence strategies in three categories, namely cost leadership, differentiation and focus. Cost leadership is how the company provides the lowest price compared to its competitors without reducing the quality of the products / services offered. Differentiation is the company's strategy to create or provide products / services that are different from competitors. Focus is that the company only focuses on certain segments in order to be able to recognize in more detail the market that they want to target.

Jaf, et al. (2015) proved that there is a positive influence between management accounting techniques and competitive advantage. The relative position of companies in their industry deter- 
mines whether the company's profitability is above or below the industry average. The fundamental basis of long-term profitability above the average is sustainable competitive advantage. There are two basic types of competitive advantages that a company can have, namely low cost or differentiation. The two basic types of competitive advantage are combined with the scope of activities the company wants to achieve, leading to three general strategies for achieving above-average performance in an industry, such as cost leadership, differentiation, and focus. The focus strategy has two variants, namely the focus of costs and the focus of differentiation. Based on these explanations, the first hypothesis is:

\section{H1: Use of Management Accounting Information System influences Competitive Advantage}

Kasravi, et al. (2017) proved that the use of management accounting has an effect on company performance, namely financial performance and organizational performance. Company performance is essentially an achievement of a business organization that can be seen from the results. The results of this performance are less precise if only seen from one dimension. Some dimensions of business performance, including 1) company performance which is measured by overall business performance compared to last year, 2) overall performance compared to its main competitors, 3) ability to earn profits or actual profitability compared to predetermined targets, 4) efficiency, namely ability to produce greater output with the same or lower input, 5) effectiveness, namely the ability of the company to achieve the stated goals, and 6) adaptivity, namely the ability of companies to adapt quickly to a changing environment. Performance can be measured by financial and non-financial aspects (Hartini, 2012). The most commonly used measures of business performance are measures of financial aspects, such as Return on Assets, probability ratios, sales growth, solvency ratios, profitability ratios, market share, and other financial measures (Majeed, 2011; Suryatini, Primiana, Kaltum, and Aziz, 2017)

In the era of globalization and digital technology, the threat faced by companies basically has not changed. There are three threats originating from the business environment, namely threats from potential competitors, the threat of products substitution, and the threat of bargaining power of suppliers and consumers. In order to successfully deal with these threats, companies must use management accounting information systems to observe and identify their environment and industry changes and competitor strategies. Mathaher (2009) proved that the use of information of management accounting systems has a positive effect on business performance. That is, the more often frequency management uses information from management accounting systems, the more business performance increases.

Mutaher (2009) also proved that the use of information of management accounting systems also indirectly influences competitive advantage through business performance. One of the mechanisms of learning, namely bencmarking as part of the management accounting system, has been used extensively in management activities to improve capabilities or market value. The use of bencmarking to increase market value will affect the level of potential profit of business performance and will ultimately lead to competitive advantage. Companies are required to respond quickly to customers. In addition, the company is also required to anticipate competitor movements and keep abreast of information technology in business development faster than its competitors. (Suryatini, et al., 2017). Tandiharjo and Devie (2015) provided empirical evidence that competitive advantage fully mediates (full mediation) the influence of competitors accounting on organization performance. This means that the influence of competitors accounting for organization performance through competitive advantage is greater than the influence of accounting competitors directly on organization performance. The conclusion is that companies that use accounting competitors in their management strategies will create competitive advantages and ultimately create a good organization performance in the company. Based on the description, the second and third hypotheses can be formulated as follows:

H2: Use of Management Accounting Information Systems influences Business Performance. H3: Use of Management Accounting Information System influences Competitive Advantage
with Business Performance as a Mediator. 


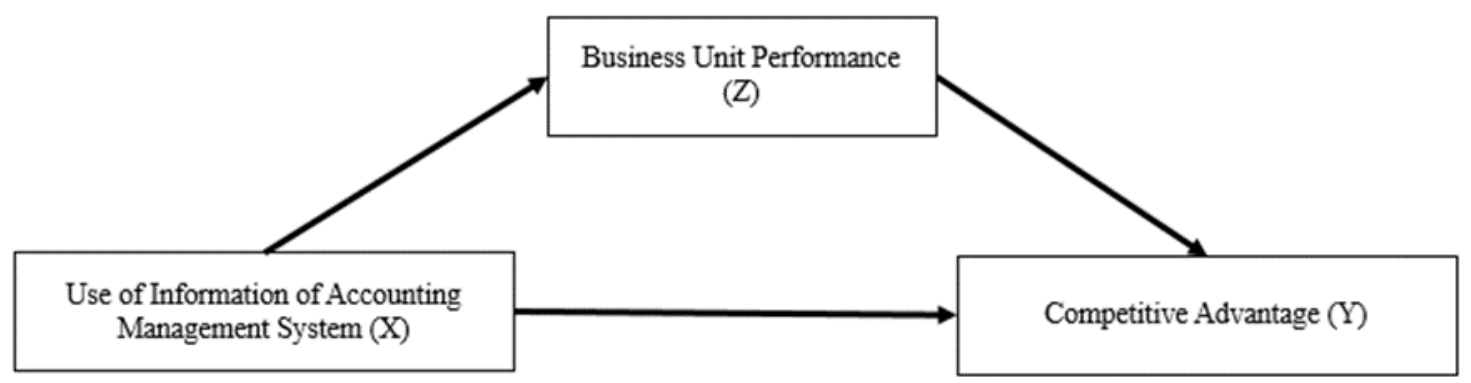

Figure 1. Research Framework

\section{RESEARCH METHOD \\ Types of Research}

In this study, the type of research used is testing the causal hypothesis. Variables are variables that influence or are called independent variables and variables that are influenced or called dependent variables. The researcher tried to examine whether the use of information of management accounting systems had an effect on competitive advantage through business performance as an intervening variable.

\section{Sample Collection Techniques}

Sampling is done by non-probability technique in the form of purposive sampling. The criteria used in this sampling are:

1. Managers in MSME-scale companies (turnover of no more than Rp. 4,800,000,000 a year) in Palembang that have at least a year experience.

2. MSMEs have adopted management information systems.

\section{Operational Definition of Variables}

Independent variable

Independent variable is variable that explain or influence other variable (Ghozali, 2011). In this study the independent variable is the use of information of management accounting system variable. Management accounting systems are formal systems designed to provide information in order to facilitate decision making and evaluate managerial activities (Apriliani, 2015). This variable is measured by questionnaires. The variable management accounting system is measured by 4 indicators, namely Broadscope, Timeliness, Aggregation, and Integration with 5 Likert scales.

\section{Dependent variable}

The dependent variable is a variable that is explained or influenced by independent variables (Ghozali, 2011). In this study the dependent variable is competitive advantage. Competitive advantage is the heart of marketing performance to face competition. Competitive advantage is defined as a benefit strategy from companies that collaborate to create more effective competitive advantages. This strategy must be designed to realize continuous competitive advantage so that companies can dominate both the old market and new markets. Competitive advantage basically grows from the values or benefits created by the company to its buyers. This variable is measured by a questionnaire. The variable of competitive advantage is measured by 5 indicators, namely price, service, quality, facility and innovation product with 5 Likert scales.

\section{Intervening variable}

Intervening variables are variables that lie between the independent variable and the dependent variable, so the independent variable does not directly explain or influence the dependent variable (Ghozali, 2011). The intervening variable in this study is the Business Unit Performance variable. Business unit performance is defined by Mia and Clarke (1999) as how high the level of achievement of planned targets, for example the achievement of production, costs, delivery schedule, service, sales volume, market share, price competition intensity, product intensity, product promotion and distribution channel. This variable is measured by a questionnaire. Business performance variables are measured by 4 indicators, namely market share, service, target achievement and product 
quality with 5 Likert scales.

\section{Analysis Method \\ Linearity test}

This test is used to see whether the specifications of the model used are correct or not. Whether the functions used in an empirical study should be linear, quadratic or empirical should be linear, squared or cubic (Ghozali, 2011). In this study, researchers used the Ramsey Test. This test was developed by Ramsey in 1969. Ramsey suggested a test called the general test of specification or RESET. To do this test we must make an assumption or belief that the correct function is a linear function.

\section{Hypothesis testing}

In this study the hypothesis was tested using Path Analysis method with the help of SPSS 17. Path analysis is an extension of multiple linear regression or path analysis is the use of regression analysis to estimate causality relationships between variables that have been applied previously based on theory (Ghozali, 2011). Path coefficients are calculated by making two regression equations which show hypothesized relationships.

The steps of testing the hypothesis are as follows:

a. Make a Management Accounting System (XSAM) regression equation against Competitive Advantage (YKB). This analysis will produce coefficients $\mathrm{c}$. The pathway is expected to be significant $(\mathrm{p}<0.05)$.

b. Creating a Management Accounting System (XSAM) regression equation on Business Unit Performance (ZKUB). This analysis produces a coefficient. The pathway is expected to be significant $(\mathrm{p}<0.05)$.

c. Creating a Management Accounting System (XSAM) regression equation and Business Unit Performance (ZKUB) against Competitive Advantages (YKB).

This analysis will produce two predictor estimation values from ZKUB and XSAM. ZKUB's prediction of YKB will produce coefficients $b$, while predictions from XSAM on YKB produce c coefficients. Pathway $b$ is expected to be significant $(\mathrm{p}<0.05)$, while path $\mathrm{c}$ 'is expected to be insignificant $(\mathrm{p}>0.05)$.

In summary, the equation can be written as follows:

Equation I: YKB $=$ a1 + cXSAM

Equation II: ZKUB $=\mathrm{a} 2+$ aXSAM

Equation III: YKB $=\mathrm{a} 3+\mathrm{c}^{\prime} \mathrm{XSAM}+\mathrm{bZKUB}$

Information:

YKB = Competitive Advantage

ZKUB $=$ Business Unit Performance

XSAM $=$ Management Accounting System

a $\quad=$ Value of regression constant coefficient

$\mathrm{b} \quad=$ Business Unit Performance regression coefficient value for Excellence Compete by controlling the Management Accounting System

c = Management Accounting System regression coefficient value for Excellence Compete

$\mathrm{c}^{\prime} \quad=$ Regression coefficient value of Management Accounting System for Performance Business by controlling the Performance of Business Units

Business Unit Performance variables are referred to as mediators if these criteria are met:

1. Equation I, XSAM significantly affects YKB

2. Equation II, XSAM significantly affects ZKUB

3. Equation III, ZKUB significantly affects YKB 


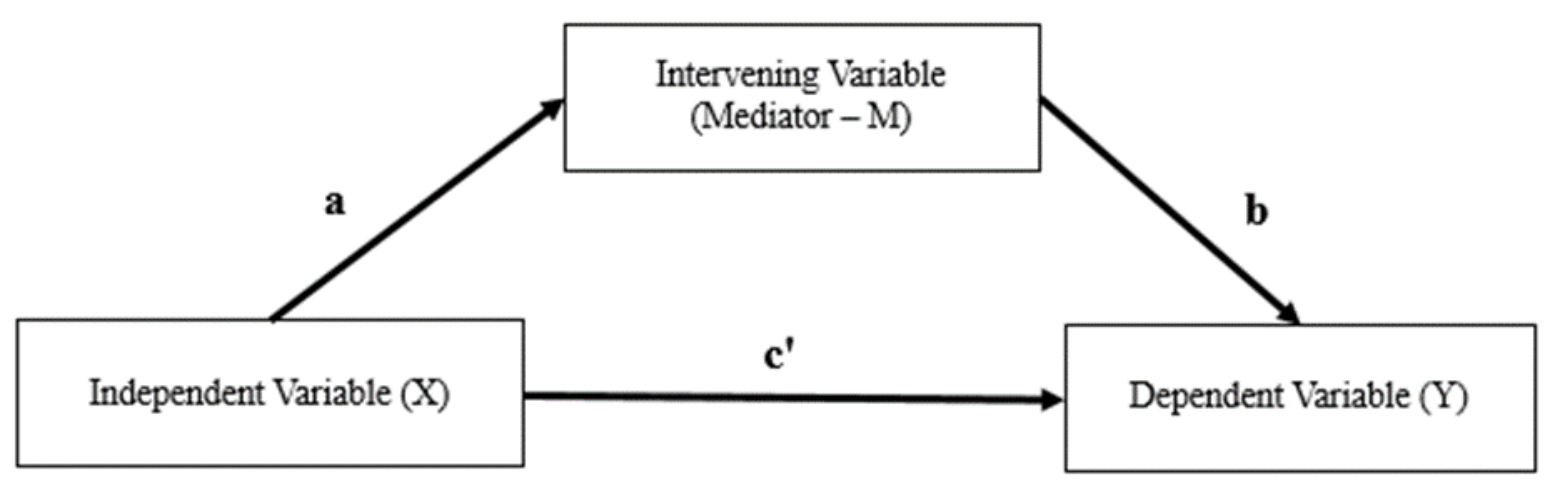

Figure 2. Research Model A

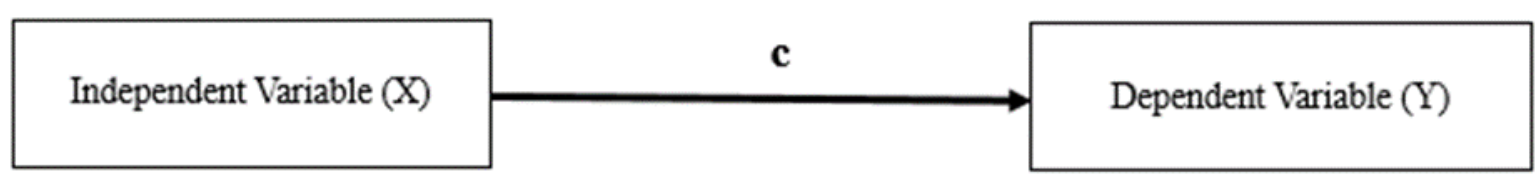

Figure 3. Research Model B

Figure 2. A illustrates a simple form of mediation if there is an indirect effect of $\mathrm{X}$ to $\mathrm{Y}$ through $\mathrm{M}$ as a mediator variable. The simple relationship between $\mathrm{X}$ and $\mathrm{Y}$ is often called the total effect with the total effect coefficient value $\mathbf{c}$ (see figure 3. B). This coefficient $\mathbf{c}$ is different from the coefficient $\mathbf{c}^{\prime}$ is the direct effect coefficient X to Y after controlling M (Figure 2. A). While in Figure 3. B the variable $\mathrm{X}$ has a direct effect on variable $\mathrm{Y}$.

The main requirements for a variable can be said as permediation variables are:

Independent variables directly and significantly influence the dependent variable.

Independent variables directly and significantly influence the mediating variables.

The total influence of the independent variables and mediating variables on the dependent variable must be greater or better the results than the direct influence on stage a. If the significance value only decreases but is not equal to zero then partial mediation occurs, but if the significance value decreases to equal to 0 then perfect mediation occurs.

This simple mediation occurs if it is fulfilled the first assumption that there is no measurement error in the mediating variable and the second that the dependent variable does not affect the mediating variable (Ghozali, 2011).

\section{RESULTS AND DISCUSSION}

Validity test

Validity tests are used to measure the validity of the questionnaires. The results of the validity test of all questionnaires of the statement items can be seen in table 1 .

Based on table 1, it can be seen that all the R-value in all questionnaires have a value above the Rtable. So it can be concluded that all the statement items are valid.

\section{Reliability Test}

Reliability is a tool to measure that a questionnaire is an indicator of a variable or construct (Ghozali, 2011). Reliability test results are shown in table 2.

A questionnaire is said to be reliable if the value of Cronbach's Alpha> 0.60. All the number of questionnaires of 26 item showed a Cronbach's Alpha of $0.923>0.60$, then all the questionnaires are reliable (Table 2).

Classical Assumption Test is used in this research since this research uses multiple linear regression analysis techniques so that the data are free from the symptoms of normality, multicollinearity, heterocedasticity and autocorrelation. 
Table 1. Questionnair es Test of Validity

\begin{tabular}{cccccc}
\hline Item & R-value & R-table & Item & R-value & R-table \\
\hline B1 & 0,674 & 0,248 & A3 & 0,583 & 0,248 \\
B2 & 0,436 & 0,248 & A4 & 0,507 & 0,248 \\
B3 & 0,527 & 0,248 & A5 & 0,556 & 0,248 \\
B4 & 0,725 & 0,248 & A6 & 0,794 & 0,248 \\
B5 & 0,641 & 0,248 & A7 & 0,623 & 0,248 \\
T1 & 0,585 & 0,248 & I1 & 0,627 & 0,248 \\
T2 & 0,547 & 0,248 & I2 & 0,733 & 0,248 \\
T3 & 0,561 & 0,248 & KB1 & 0,317 & 0,248 \\
T4 & 0,611 & 0,248 & KB3 & 0,347 & 0,248 \\
A1 & 0,579 & 0,248 & KB4 & 0,394 & 0,248 \\
A2 & 0,566 & 0,248 & & & \\
\hline
\end{tabular}

Source: Data Processed

Tabel 2. Reliability Test

\begin{tabular}{cc}
\hline Cronbach's Alpha & N of Items \\
\hline 0,926 & 26 \\
\hline
\end{tabular}

Source: Data Processed

Normality Test

Table 3. Normality Test

\begin{tabular}{lrrrrrrr}
\hline & \multicolumn{3}{c}{ Kolmogorov-Smirnov $^{\mathrm{a}}$} & \multicolumn{4}{c}{ Shapiro-Wilk } \\
\cline { 2 - 8 } & Statistic & Df & & Sig. & Statistic & df & \multicolumn{1}{c}{ Sig. } \\
\hline SAM & .096 & 45 & $.200^{*}$ & .979 & 45 & .582
\end{tabular}

a. Lilliefors Significance Correction

*. This is a lower bound of the true significance.

Source: Data Processed

Normality Test results show that the value of Kolmogorov-Smirnova Sig.> 0.05 which is 0.96 . This value is greater than the significance value of $0.05(5 \%)$. Based on these results it can be concluded that the data is normally distributed (Table 3 ).

\section{Multicollinearity Test}

The multicollinearity test aims to test whether the regression model found a correlation between independent variables. Multicollinearity test results can be seen in table 5.4 below.

Table 4. Multoliniear ity Test

\begin{tabular}{|c|c|c|c|}
\hline \multicolumn{4}{|c|}{ Coefficients $^{a}$} \\
\hline \multirow[b]{2}{*}{ Model } & & \multicolumn{2}{|c|}{ Collinearity Statistics } \\
\hline & & Tolerance & VIF \\
\hline \multirow[t]{2}{*}{1} & XSAM & .959 & 1.043 \\
\hline & ZKUB & .959 & 1.043 \\
\hline
\end{tabular}

a. Dependent Variable: YKB

Source: Data Processed 
All Tolerance values for each variable are above 0.1 and all VIF values for each variable are below the value 10. Based on these results (table 4), it can be concluded that the data is free from the problem of multicollinearity.

\section{Heterocedasticity test}

From the scatterplot it can be seen that the points spread randomly, either at the top of zeros or at the bottom of zeros from the vertical axis or Y axis (figure 2). Thus it can be concluded that there is no heteroscedasticity in the regression model.

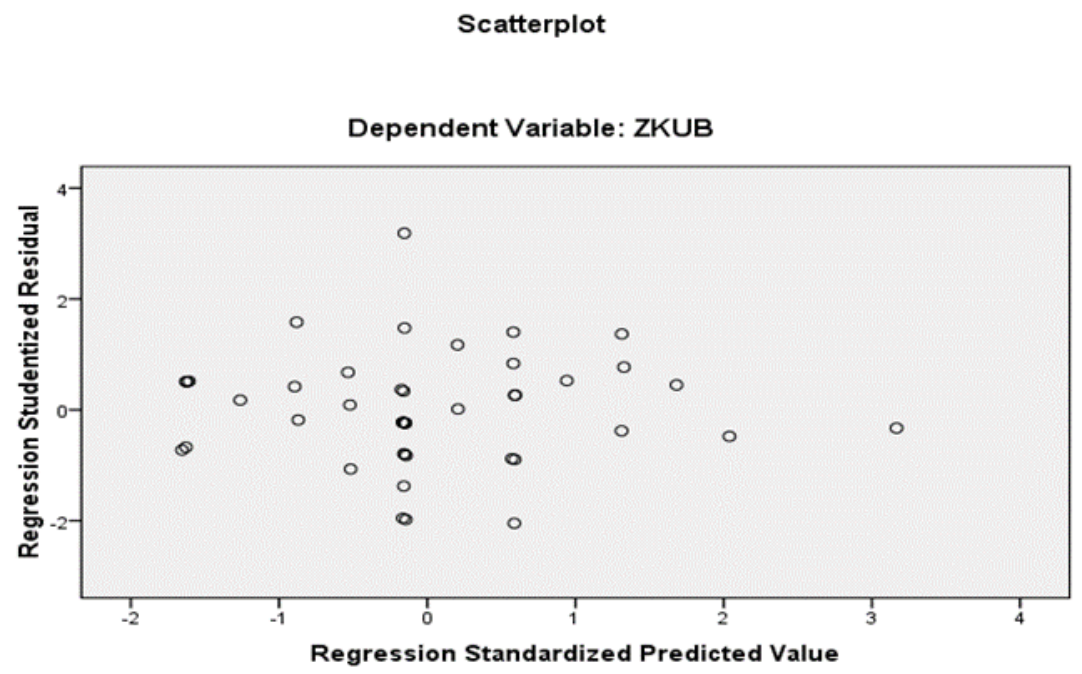

Figure 2. Heterocedasticity Test

\section{Hypothesis testing}

Table 5. Regression of Management Accounting Systems and Competitive Advantages

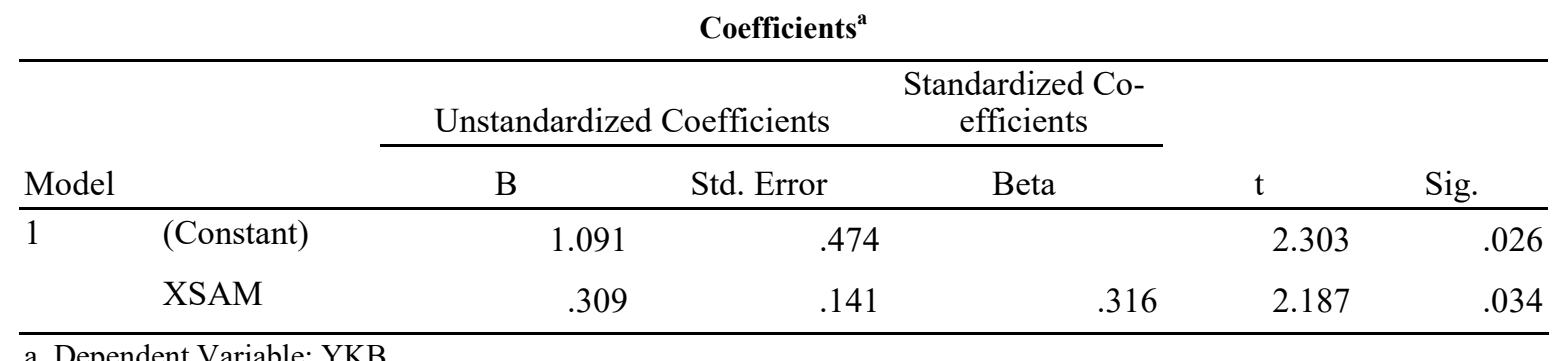

a. Dependent Variable: YKB

Source: Data Processed

From the output in table 5, it is revealed that the value of $\mathbf{c}$ is equal to $0.309(\Omega \mathrm{c}=0.316)$, with tc $=2.187$ and significance $p<0.05(0.034)$. Thus XSAM significantly affects YKB. The first hypotheses is accepted.

From the output in table 6 , it is known that the coefficient $\mathbf{a}$ is equal to $0.312(\mathrm{Ba}=0.307)$, with ta $=2.116$ and significance value $p<0.05(0.040)$. Thus XSAM significantly affects ZKUB. The second hypotheses is accepted.

From the output in table 7 , it is showed that the coefficient value of $\mathbf{b}$ is $0.591(B b=$ $0.614)$, with $\mathrm{tb}=5.072$ and significance value $\mathrm{p}<0.05(0.000)$. Thus ZKUB significantly affects YKB. While the value of the coefficient is $0.125\left(B c^{\prime}=0.128\right)$, with $\mathbf{c}^{\prime}=1.055$ and significance value $\mathrm{p}>0.05(0.298)$. Thus XSAM does not affect YKB. The third hypotheses is accepted. 
Table 6. Regr ession of Use of Management Accounting Information Systems for Business Unit Performance

\begin{tabular}{|c|c|c|c|c|c|c|}
\hline \multicolumn{7}{|c|}{ Coefficients $^{\mathrm{a}}$} \\
\hline & & \multicolumn{2}{|c|}{ Unstandardized Coefficients } & $\begin{array}{l}\text { Indardized Co- } \\
\text { efficients }\end{array}$ & \multirow[b]{2}{*}{$\mathrm{t}$} & \multirow[b]{2}{*}{ Sig. } \\
\hline \multicolumn{2}{|c|}{ Model } & $\mathrm{B}$ & Std. Error & Beta & & \\
\hline \multirow[t]{2}{*}{1} & (Constant) & 1.156 & .494 & & 2.338 & .024 \\
\hline & XSAM & .312 & .147 & .307 & 2.116 & .040 \\
\hline
\end{tabular}

a. Dependent Variable: ZKUB

Source: Data Processed

Table 7. Regression of Management Accounting Systems and Business Unit Performance on Competitive Advantages

\begin{tabular}{|c|c|c|c|c|c|c|c|}
\hline \multicolumn{8}{|c|}{ Coefficients $^{\mathrm{a}}$} \\
\hline & & \multicolumn{3}{|c|}{ Unstandardized Coefficients } & \multirow{2}{*}{$\begin{array}{c}\text { Standardized Co- } \\
\text { efficients } \\
\text { Beta } \\
\end{array}$} & \multirow[b]{2}{*}{$\mathrm{t}$} & \multirow[b]{2}{*}{ Sig. } \\
\hline \multicolumn{2}{|c|}{ Model } & $\mathrm{B}$ & & Std. Error & & & \\
\hline \multirow[t]{3}{*}{1} & (Constant) & & .409 & .401 & & 1.020 & .314 \\
\hline & XSAM & & .125 & .118 & .128 & 1.055 & .298 \\
\hline & ZKUB & & .591 & .116 & 614 & 5.072 & .000 \\
\hline
\end{tabular}

a. Dependent Variable: YKB

Source: Data Processed

Since the three criteria for moderator variables are met, plus the Management Accounting System variable becomes insignificant towards the Competitive Advantage variable when the Business Unit Performance variable is included in the analysis, it is evident that Business Unit Performance mediates the relationship between the Management Accounting System and Competitive Advantage. All three Hypothesis are accepted.

\section{Discussion}

Management accounting system is a procedure and a formal system that uses information to maintain and provide alternatives to various corporate activities. One of the functions of a management accounting system is as an important source of information to help managers control their activities, and reduce environmental uncertainty in an effort to achieve organizational goals successfully (Lathifah , 2012). The view of Management Accounting System is a system that provides benchmarking in monitoring additional information on the company's internal and traditional historical information that produces a management accounting system.

The Effect of Use of Management Accounting Information Systems on Competitive Advantage. Competitive advantage comes from many different activities carried out by companies in designing, producing, marketing, delivering, and supporting their products. Competitive advantage is the ability of a company to achieve economic benefits above the profits that competitors can achieve on the market in the same industry (Porter, 1985).

The results of the study prove that the use of management accounting system information influences competitive advantage. The results of this research support the research of Jaf, et al. (2015), Setyawati (2013) and Motaher (2009). The results of Setyawati's research (2013) show that market orientation and entrepreneurial orientation influence competitive advantage. Companies that have competitive advantages always have the ability to understand changes in market structure and are able to choose effective marketing strategies. 
The Effect of Use of Management Accounting Information Systems on Business Performance The results of the study prove that the use of management accounting system information affects business performance. The results of this research support Kasravi's research, et al. (2017), Hartini (2012), Lathifah (2012) and Motaher (2009).

Business performance is a determining factor in the survival of a company. Business performance is divided into two types, individual performance and organizational performance. Business unit performance is defined by Mia and Clarke (1999) as how high the level of achievement of planned targets, for example the achievement of production, costs, delivery schedule, service service, sales volume, market share, price competition intensity, product intensity, product promotion and channel distribution

The Effect of Use of Management Accounting Information Systems on Competitive Advantage with Business Performance as a Mediator

The results of the study proves that competitive advantage acts as a mediating variable between the use of management accounting information systems and business performance. These results support the results of research by Tandiharjo and Devie (2015), Setyawati (2013) and Motaher (2009). Setyawati (2013) proved that competitive advantage variables have an intervening influence from the relationship between entrepreneurial orientation (which is the practice of management accounting systems) and company performance.

The use of management accounting information systems can help managers make decisions and overcome existing competition so they can gain competitive advantage. In order to survive and succeed, management must gain a competitive advantage by being better than competitors in doing valuable things for customers. To produce that company needs to improve its performance, so that targets can be achieved so that they can survive and develop in the face of competition.

\section{CONCLUSION}

Based on the results of the test, it was concluded that the Business Unit Performance was able to mediate the relationship between Management Accounting Systems and Competitive Advantages. This study has several limitations. First, this study uses the object of research by companies of MSMEs in Palembang City. While MSMEs in the city of Palembang consist of various types of business fields and have a varying percentage of profit. Further research is recommended to be able to carry out specifications to similar MSMEs, so that the results can be concluded specifically.

Second, the data collection technique is limited to only using a questionnaire so that it is less able to gather information from respondents. Further research is suggested to be able to add data collection techniques by conducting interview techniques so that the information obtained will be broader

\section{REFERENCES}

Apriliani, Lydia, (2015). Faktor-Faktor yang Mempengaruhi Keunggulan Bersaing dalam Upaya Meningkatkan Market Share (Studi Kasus pada Smartphone IPhone di Semarang), Skripsi, Universitas Diponegoro, http://eprints.undip.ac.id/46548/1/21_APRILIANI.pdf

Chandra, Nofi (2018). Digitalisasi Pasar UMKM, https://news.detik.com/kolom/d-3979754/ digitalisasi-pasar-umkm

Choiri, Eril Obeit, (2018). Lima Strategi Mengembangkan UMKM untuk Menghadapi Pasar Global, $\quad$ https://www.jurnal.id/en/blog/2018-5-strategi-untuk-mengembangkan-umkm-diindonesia-menghadapi-pasar-global/

Danial, Deni Muhammad (2017). Meningkatkan Keunggulan Bersaing Usaha Kecil dan Menengah (Upaya Meningkatkan Kesejahteraan Masyarakat), Jurnal Ilmu Sosial dan Ilmu Politik, Vol. 7, No. 1, pp. 13-21. https://journal.uinsgd.ac.id/index.php/jispo/article/view/ 1732/1176 
David, F. R. (2011). Strategic Management: Concepts and Cases (13th ed.). New Jersey, NJ: Prentice Hall.

Ghozali, Imam, (2011). Aplikasi Analisia Multivariate dengan Program SPSS 19, Universitas Diponegoro, Semarang.

Hartini, Sri, (2012). Peran Inovasi: Pengembangan Kualitas Produk dan Kinerja Bisnis, Jurnal Manajemen dan Kewirausahaan, Vol. 14 No. 1, pp. 82-88, http://puslit2.petra.ac.id/ejournal/ index.php/man/article/viewFile/18375/18200

Jaf, Rizgar Abdullah Sabir, Sadar Abdullah Sabr, and Karim Amin Nadir, (2015). Impact of Management Techniques on Achieve Competitive Advantage, Research Journal of Finance and Accounting, Vol. 6 No.4, pp. 84-98, https://www.iiste.org/Journals/index.php/RJFA/ article/ viewFile/19972/20500

Kasravi, N., Mortega Ghasemi, and Najafi Zadeh, (2017). The Effect of Management Accounting on Financial Performance and Organizational Performance in Tafresh University, Journal of Internet Banking and Commerce, December 2017, vol. 22, no. 3, pp. 1-10, http:// www.icommercecentral.com/open-access/the-effect-of-management-accounting-financialperformance-and-organizational-performance-in-tafresh-university.pdf

Lathifah, Ifah. 2012. Peran Karakteristik Sistem Akuntansi Manajemen sebagai Mediator Hubungan Antara Ketidakpastian Lingkungan dengan Kinerja Manajerial. Jurnal review Akuntansi dan Keuangan, Vol. 2 No. 2. Hal. 313-322

Majeed, Sadia, (2011). The Impact of Competitive Advantage on Organizational Performance, European Journal of Business and Management, Vol. 3 No. 4, pp. 191-196, https:// pdfs.semanticscholar.org/40ce/1b47e6c16fe01de655e03eb1a1b5df3fbbf2.pdf

Meryana, Ester. (2012). Tiga Hal yang Buat UMKM Tahan Krisis, Kompas.com, https:// ekonomi.kompas.com/read/2012/03/28/11093274/Tiga.Hal.yang.Buat.UMKM.Tahan.Krisis

Mia, L. and Clarke, B., (1999). Market competition, management accounting systems and business unit performance, Management Accounting Research, 10, June, pp. 137-158, https:// www.academia.edu/21819326/

Market_competition_management_accounting_systems_and business_unit_performance

Muthaher, Osmad (2009). Analisis Pengaruh Penggunaan Informasi Sistem Akuntansi Manajemen terhadap Keunggulan Bersaing melalui Kinerja Bisnis, Jurnal Akuntansi Indonesia (JAI), vol. 5 No.2, Juli, pp. 217-230, http://unissula.ac.id/wp-content/uploads/2012/04/osmad.pdf

Porter, M.E. (1985). Competitive Advantage: Creating and Sustaining Superior Performance (1st ed.). New York, NY: Free Press.

Putra, Dwi Aditya, (2018). UMKM Sumbang 60 Persen ke Pertumbuhan Ekonomi Nasinal, https://www.liputan6.com/bisnis/read/3581067/umkm-sumbang-60-persen-ke-pertumbuhanekonomi-nasional

Setyawati, H. (2013). Pengaruh Orientasi Kewirausahaan dan Orientasi Pasar terhadap Kinerja Perusahaan Melalui Keunggulan Bersaing Dan Persepsi Ketidakpastian Lingkungan Sebagai Prediksi Variabel Moderasi (Survey pada UMKM Perdagangan di Kabupaten Kebumen). Fokus Bisnis: Media Pengkajian Manajemen Dan Akuntansi, 12(2). Retrieved from http://journal.stieputrabangsa.ac.id/index.php/fokbis/article/view/3

Suryaningrum, D.H. (2012). Knowledge Management and Performance of Small and Medium Entities in Indonesia. International Journal of Innovation, Management, and Technology, Vol. 3, No. 1. February, pp. 35-41.

Suryatini, D., I. Primiana, U. Kaltum, and Y. Aziz, (2017). The Effect of Relationship and Competitive Strategy on Business Performance of Rattan Industry in Java, Academy of Strategic Management Journal, Vol. 16 Issue 3, pp. 1-10, https://www.abacademies.org/articles/ The-effect-of-relationship-and-competitive-strategy-on-business-performance-of-rattanindustry-in-java-1939-6104-16-3-118.pdf 
Tandiharjo, Alan Hartono and Devie, (2015). Pengaruh Kompetitor Accounting sebagai Strategic Management Accounting Techniques terhadap Competitive Advantage dan Organization Performance, Business Accounting Review, Vol. 3 No.1, January, pp. 168-179, https:// media.neliti.com/media/publications/185267-ID-none.pdf 
http://jasf.upnjatim.ac.id/index.php/jasf/article/view/22 